\title{
MAMMALIAN CELL CULTURE CLARIFICATION: A CASE STUDY USING CHIMERIC ANTI-CEA MONOCLONAL ANTIBODIES
}

\author{
Mohamed Ali Abol Hassan ${ }^{1}$, Abdul Wahab Mohammad ${ }^{2}$ \\ AND BADARULHISAM ABDUL RAHMAN ${ }^{1}$ \\ ${ }^{1}$ Department of Process Science, \\ Innobiologics Sdn Bhd, Nilai, Negeri Sembilan, Malaysia. \\ ${ }^{2}$ Department of Chemical and Process Engineering, \\ Faculty of Engineering and Built Environment, \\ Universiti Kebangsaan Malaysia, Bangi, Selangor, Malaysia. \\ wahabm@vlsi.eng.ukm.my
}

\begin{abstract}
The extracellular expression of monoclonal antibodies (mAbs) in mammalian cell culture provides both opportunities and restrictions for the design of robust harvest and clarification operations. With advances in cell culture media and cell lines, it is now possible to achieve high titers of over $5 \mathrm{~g} / \mathrm{l}$ for mAbs. However, Mammalian cells are sensitive to breakage due to shear stress that can result in release of proteases and other host cell proteins (HCPs) which eventually affects product stability and purity. There is larger number of mAbs undergoing clinical development and it has placed significant importance on platform technologies of process development. Generally, Centrifugation and microfiltration are the primary harvest techniques used in the industry and depth filtration is also used as a step operation on clarification. This study compares the unit operations; centrifugation, microfiltration and depth filtration for maximum recovery of monoclonal antibodies. The results have shown that the depth filtration as more suitable operation for mammalian cell culture clarification since it gives $96 \%$ recovery of mAbs in comparison to centrifugation and microfiltration.
\end{abstract}

ABSTRAK: Pengungkapan luar sel dari antibodi monoklon (monoclonal antibodies (( $m A b s)$ dalam kultur sel mamalia memberi ruang dan batasan terhadap reka bentuk penuaian yang cekap dan penerangan operasi. Dengan kemajuan dalam media sel kultur dan cell lines (produk yang berupa sel kekal yang digunakan untuk tujuan kajian biologi), kini adalah berkemungkinan untuk memperolehi titer tinggi melebihi 5g/l untuk mAbs [2]. Walaupun begitu, sel mamalia sensitif terhadap retakan disebabkan tegasan ricih yang menyebabkan pengeluaran protease dan hos sel protein yang lain, (host cell proteins (HCPs)) akhirnya mempengaruhi kestabilan dan keaslian produk. Terdapat $m A b s$ dalam jumlah besar yang masih menjalani pembangunan klinikal dan sesungguhnya ini penting sebagai satu landasan teknologi dalam proses pembangunan. Umumnya pengemparan dan mikropenurasan merupakan teknik asas tuaian dalam industri dan penurasan dalam juga digunakan sebagai satu pengendalian langkah dalam penjelasannya. Kajian ini membandingkan operasi unit: pengemparan, mikropenurasan dan penurasan dalam untuk perolehan antibodi monoklon yang maksima. Keputusan menunjukkan penurasan dalam adalah operasi yang lebih sesuai untuk penjelasan kultur sel mamalia kerana ia memberikan perolehan $96 \% m A b s$ berbandingkan dengan cara pengemparan dan mikropenurasan.

KEYWORDS: monoclonal antibodies (mAbs); centrifugation; microfiltration; depth filtration; host cell proteins (HCPs) 


\section{INTRODUCTION}

Over the last decade, advances in recombinant protein technologies have overshadowed efforts in understanding the specific needs and problems of downstream processing (DSP). As a result the operational limitations of DSP, along with its costs, are now widely accepted as a major obstacle in the ability to rapidly develop and place commercially viable biotechnological products in the market place. In particular, the monoclonal antibodies (mAbs) occupy an important niche within the biopharmaceutical industry [1]. Currently, there are more than 27 monoclonal antibodies commercially approved and they are used to treat a wide range of clinical indications [3]. The wide range of mAbs reflects their ability to target a number of cellular receptors and cytokines, either to block or to augment their function, to induce their destruction through antibodydependent cell cytotoxocity (ADCC), or to activate the complement cascade [4]. Among the monoclonal antibodies, the chimeric anti-carcinoembryonic antigen (CEA) monoclonal antibody is useful for the immunocytochemical detection of colon cancer tissue [5]. In 1965, Drs. Gold and Freedman from McGill University were the first to describe the present tumor associated carcinoembryonic antigen (CEA) in human colon cancer tissue extracts [6]. Anti-CEA could be measured in serum from patients with colorectal and other carcinomas using sensitive radioimmunoassay [7]. Carcinoembryonic antigen has proven to be suitable target antigen for the detection of primary and metastatic colorectal and is currently being explored as a possible target for antibody- mediated therapy [8].

Generally, the cell culture process development and commercial production for monoclonal antibody can be divided into two major areas i.e. upstream and downstream. The upstream operations include cell line development, media optimization, and cell culture process optimization. The downstream operations comprises of cell harvest, antibody capture, viral inactivation, and polishing steps. Harvest of biotechnological products from cell culture or fermentation process streams is often performed by a combination of several unit operations due to the gelatinous, compressible and of low density nature of cell culture. Eventually, the drivers for the process design include maximizing product recovery, scalability, robustness and clarification of the process stream while operating in a physical and chemical environment where the product is stable.

The harvest approach is dependent on the mode of expression of the target protein. For intracellular expression, the first step is cell concentration and followed by cell disruption to release the target protein into solution. After cell disruption, the cell debris is removed and protein solution is further clarified using filtration. On the other hand, the first step in harvest for the extracellular expression of target protein is to remove the cells via centrifugation or microfiltration or depth filtration. The density of the cell culture, shear sensitivity of the cells and stability of the product are all important cell line-specific characteristics that influence the harvest process design.

Relative to other types of cells (bacteria, yeasts, fungi and plants) used in expression of protein products, mammalian cells are favored because of the complexity and the large size of mAbs, which comprise two heavy and two light chains joined together by covalent and noncovalent bonds to achieve the well-known Y-shaped conformation. Furthermore, mAbs are glycoproteins whose glycan chains could play a significant role in their biological activity, and only mammalian cells produce the correct glycan chain structures [9]. Mammalian cell culture systems such as Chinese hamster overy (CHO), SP 2/0 and NSO cells express monoclonal antibodies extracellularly [10-11,12]. With advances in cell culture media and cell lines; it is now possible to achieve high titers and high cell densities 
Abol Hassan et al.

in fermentation systems. However, mammalian cells exhibit very low shear resistance which tends to easier cell breakage that leads to release of proteases and other host cell proteins into the broth. This can affect product stability and purity. Cell culture media are fairly rich and can promote bacterial growth in the event of contamination. As a result, the hold times for both the production bioreactor after the termination of cell culture and for the harvest operations need to be limited.

The large number of mAbs undergoing clinical development has placed significant pressure on process development organizations to harmonize efforts through the adoption of platform technologies. This paper will focus on harvest of mammalian cells (NSO) and the performance comparison of the above mentioned unit operations for clarifying cell broth in order to maximize the recovery of monoclonal antibodies.

\section{METHODOLOGY}

Figure 1 illustrates the different approaches that were compared. Option A involves a combination of centrifugation and depth filtration, Option B consists of two depth filtration as primary and secondary and Option $\mathrm{C}$ has a microfiltration step for clarification of the feed stream.

\subsection{Materials}

The fermentation broth was the NSO cells with 5\% Fetal Bovine Serum (FBS) with the following profile: total viable cell density: $2.07 \times 10^{6}$ cells $/ \mathrm{ml}$ with overall $75.85 \%$ and the target protein: Chimeric Anti-CEA was expressed extracellularly (Table 1 shows the culture specification).

Table 1: Culture specifications during harvest.

\begin{tabular}{|l|c|}
\hline Turbidity & $96 \mathrm{NTU}$ \\
\hline Mass of total protein & $5735.9 \mathrm{mg}$ \\
\hline Mass of protease & $0.859 \mathrm{mg}$ \\
\hline $\begin{array}{l}\text { Mass of target product (Chimeric } \\
\text { Anti-CEA mAbs) }\end{array}$ & $16.2 \mathrm{mg}$ \\
\hline
\end{tabular}

The high cell density monoclonal antibodies culture broth was produced at laboratory scale. The centrifuge used for the clarification work is sigma lab centrifuge 4K15 (type: tubular bowl centrifuge/solid wall centrifuge).

Two types of single use, disposable depth filter is carefully chosen among the other filters with the $1^{\text {st }}$ filter (Millistak+HC mini capsule -DOHC) carries retention range of 8$4 \mu \mathrm{m} / 1.5-0.6 \mu \mathrm{m}$ as primary filter and $2^{\text {nd }}$ filter (Millistak $+\mathrm{HC}$ mini capsule $-\mathrm{B} 1 \mathrm{HC}$ ) retention range of $0.7-0.3 /<0.1 / 0.1 \mu \mathrm{m}$ as secondary filter. Both filters are made of cellulosic membrane with inorganic filter aid.

Flat cassette cellulose based membrane with pore size of $0.45 \mu \mathrm{m}$ and the surface area of $0.1 \mathrm{~m}^{2}$ was obtained from Sartorius Stedim and used on Kvick lab system, which is full featured with rotary lobe pump that can be used for shear-sensitive products, for microfiltration. 
For the target protein analysis, Enzyme Linked Immunosorbant Assay (ELISA) was performed using the Pierce Human IgG, whole molecule (cat no: 31154, from Thermo Scientific) was used as Standard antibody, Anti-Human IgG : Fc Specific (cat no: I2136, from Sigma-Aldrich) as capture antibody, Anti-Human IgG: $\gamma$-chain specific peroxidase conjugate (cat no: A6029, from Sigma-Aldrich) as secondary antibody and Ultra TNB substrate (cat no: 010M1107, Sigma-Aldrich) for detection. The protease concentration and total protein present in the sample was quantified by Colorimetric Protease Assay Kit (Pierce, U.S) and BCA Protein Assay Kit (Pierce, U.S) respectively.

\subsection{Experimental Methods}

The sample was centrifuged at ambient temperature with the relative centrifugal force (RCF) of $4000 \times g$ for 10 minutes. After centrifugation, centrate was stored in the cold room $\left(\sim 4^{\circ} \mathrm{C}\right)$ prior to next process. During depth filtration, depth filters were first flushed with sufficient amount of buffer to thoroughly wet filter media and reduce the level of extractables. The centrate that was agitated and maintained at cold room $\left(2-8^{\circ} \mathrm{C}\right)$ was then pumped using Watson-Marlow ${ }^{\circledR}$ peristaltic pump through the filters at constant flow rate of 200LMH. Filtrate volume and differential pressure were recorded at different time intervals. Similarly, the procedure was followed for both primary \& secondary depth filtration.

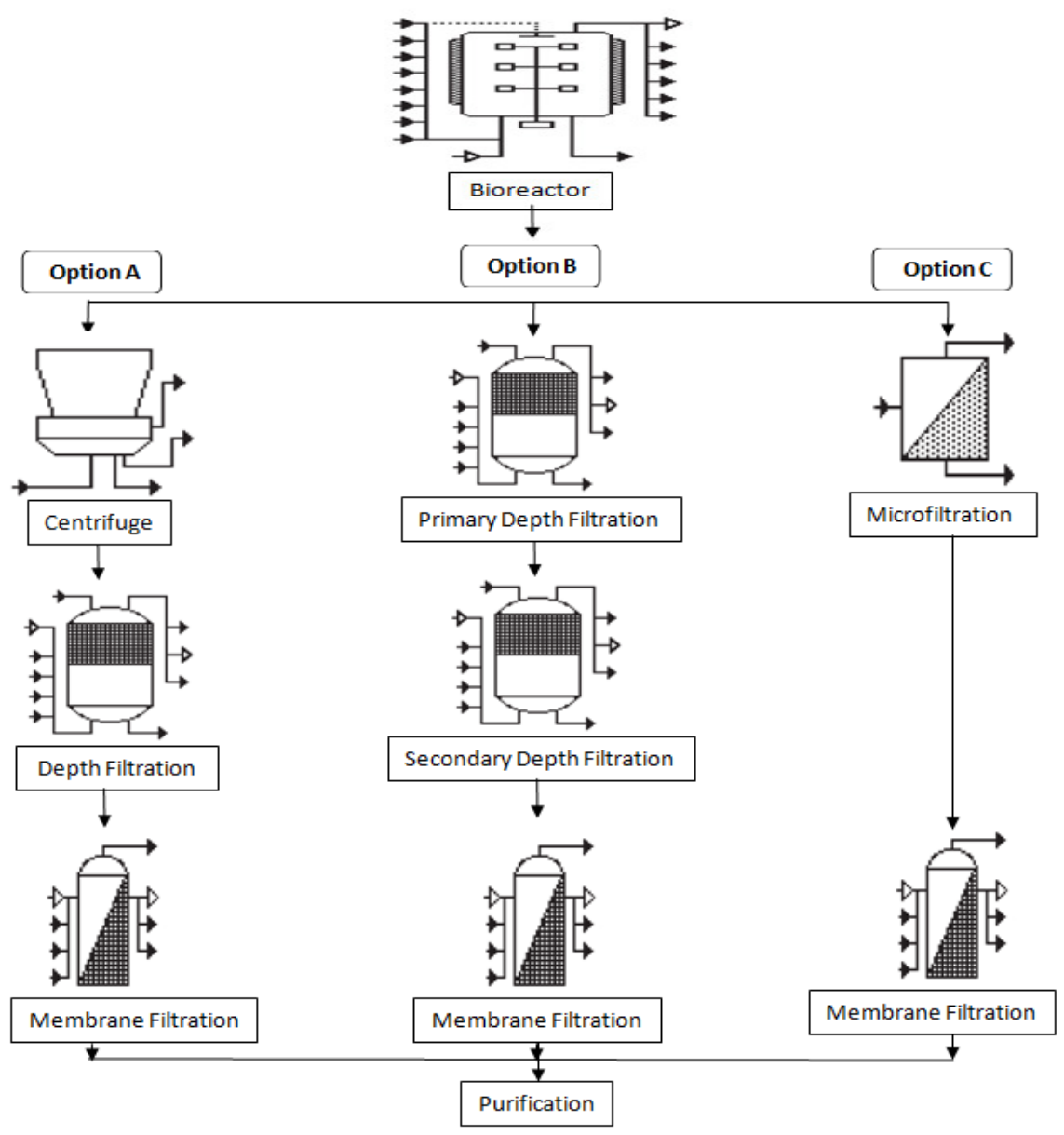

Fig. 1: The outline for comparison of unit operations on harvest and Clarification of Mammalian cell culture [2]. 
The apparatus used to perform the microfiltration experiment is presented schematically in Fig. 2. A rotator lobe pump was used to circulate the fermentation broth and controls permeate flux. Normalized clean water permeability was tested prior to loading of feed material to the MF system. The targeted protein is stable in postproduction broth at room temperature. Therefore, during MF process, the retentate was maintained at room temperature $\left(23-26^{\circ} \mathrm{C}\right)$ to reduce fluid viscosity and maximize flux. The parameters were set as feed pressure (Pin) as 7 psi, permeate pressure $(\mathrm{Pp})$ as 2 psi and retentate pressure (Pr) maintained at zero.

The target protein (Chimeric Anti-CEA mAbs) recovery was determined by ELISA (Enzyme-Linked Immunosorbant Assay). In ELISA, Human IgG, whole molecule was used as Standard. First, the 96-well plate were coated with $100 \mu \mathrm{l}$ of Anti-Human IgG : Fc Specific diluted in coating solution in the ratio of 1:1000 and incubated for overnight. After rinsing with 1 X $200 \mu \mathrm{l}$ washing buffer, $200 \mu$ l blocking buffer was added and incubated for 2 hours followed by washing with 3 X $200 \mu$ l washing buffer. A $100 \mu 1$ sample or standard solution was added to each well followed by adding secondary antibody - Anti-Human IgG: $\gamma$-chain specific peroxidase conjugate diluted in 1xPBS in the ratio of 1:2500 and incubated for 2 hours. Then, the plate was rinsed with 3 X $200 \mu 1$ washing buffer followed by addition of $100 \mu \mathrm{TNB}$ substrate and incubated for $15 \mathrm{mins}$. Lastly, the reaction was stopped by $2.5 \mathrm{M}$ sulfuric acid. The formation of golden yellowcolored absorbance was measured at a wavelength of $405 \mathrm{~nm}$ via microplate reader (BioTek Instruments, Inc., Winooski, VT). Samples were diluted 100 to 12,000-fold with diluent $(0.01 \%$ Tween 20 in $1 \mathrm{X}$ PBS) prior to assay depending on the antibody concentration.

The shear sensitive mammalian cells release proteases during breakage of cells in any unit operations. The amount of protease present in the sample was determined using Colorimetric Protease Assay Kit and the total protein was quantified using BCA Protein Assay Kit (Pierce, U.S). Target protein concentration was determined for feed, centrate, permeate, retentate and filtrate pools were used to calculate protein recovery. Turbidity was measured on the feed, centrate and filtrate samples using Hach ${ }^{\circledR}$ portable turbidity meter in the unit of NTU. Mass balances were performed using weights of all the feeds, centrates and filtrates. All the collection tanks were tared so that the accurate mass and volumes could be calculated for mass balance.

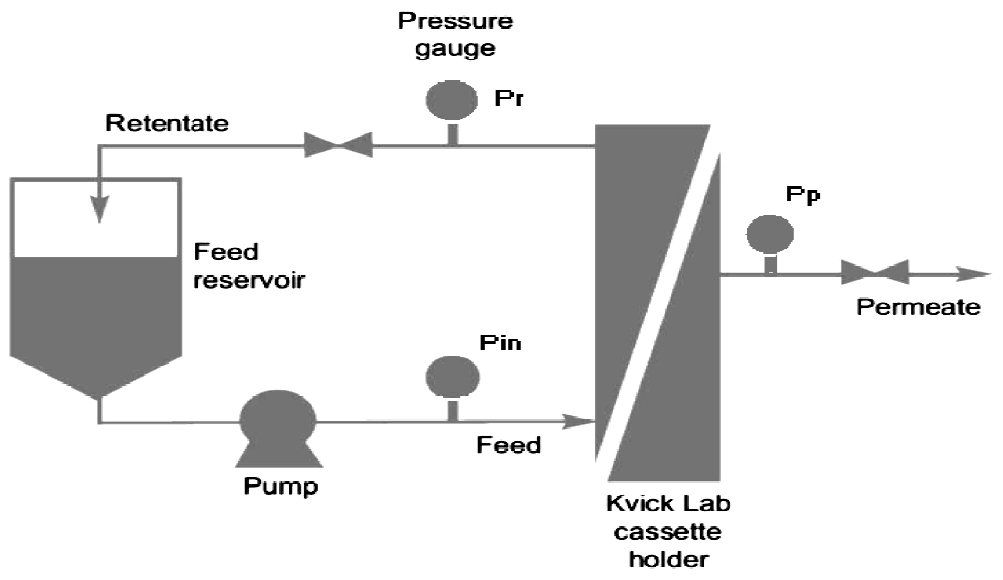

Fig. 2: Basic flow path for cross flow filtration process 


\section{RESULTS AND DISCUSSION}

The harvested volume was divided proportionally on Centrifugation followed by depth filtration (option A), primary and secondary depth filtration (option B) and microfiltration on tangential flow filtration (TFF - option $\mathrm{C}$ ).

\subsection{Centrifugation}

This unit operation in Option A used a sigma lab centrifuge 4K15 having universal swing, threaded bucket capable of 4 X $50 \mathrm{ml}$ Falcon tubes. Therefore, the sample was divided into $40 \mathrm{ml}$ per $50 \mathrm{ml}$ Falcon tube. After centrifugation, the supernatant was transferred to a beaker and the pellets were discarded. The samples were taken before and after the operation for turbidity measurement, total protein determination, quantification of protease released and recovery of target protein (Table 2 shows the results on option A). The volume recovered after the centrifugation followed by depth filtration was $97 \%$.

Generally, the ratio of equivalent area (termed as sigma factor, $\sum$, in disk stack centrifuge) and the flow rate through the chamber, $\mathrm{Q}$, is maintained on scale up process. However, keeping $\mathrm{Q} / \sum$ ratio identical may still lead to underperformance at a larger scale. This lower efficiency is attributed to shear damage or hindered settling in centrifugation [13]. The shear happens during centrifugation damages cells \& cell debris and eventually releases proteases which are highly evident in this study as Option A shows $12.1 \mu \mathrm{g} / \mathrm{ml}$ of protease concentration and also generates submicron particles that were separated by depth filtration. Shear sensitivity is main concern for mammalian cell culture clarification since it is main cause for release of proteases that could affect the stability of the target protein and host cell proteins (HCP) and DNA, all of which can reduce product quality as well [2].

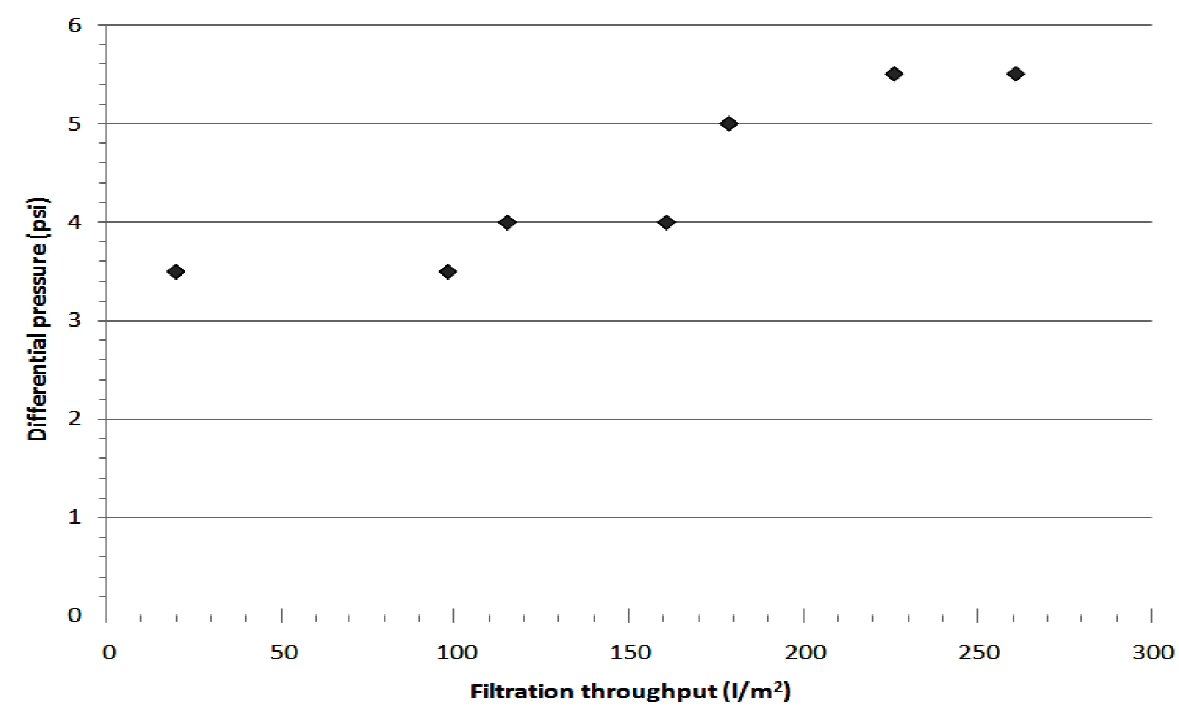

Fig. 3: Filtration profile of Millipore depth filter carried out at flow rate of 200LMH

$(\diamond$ Pressure).

\subsection{Depth Filtration}

This option involved using a two depth filters from Millipore (Millistak+ HC mini capsule filters). First was the more open filter in primary depth filtration followed by a tighter grade filter in secondary depth filtration. The pressure and filtrate flow rate readings were taken. In this no turbidity breakthrough was observed however pressure 
breakthrough is normally the basic limitation for constant flow depth filtration (Fig. 3). In this constant flow filtration at 200LMH flux rate, the flow was steady and smoother with pressure increase only until 6 psi since maximum allowable differential pressure for minicapsule filter is $22 \mathrm{psi}$. The samples were taken before and after the operation for turbidity measurement, total protein determination, quantification of protease released and recovery of target protein (Table 2 shows the results on Option B). The volume recovered after the primary and secondary depth filtration about $94 \%$.

When the solids level is low, fine particles bind to the filter media due to electrostatic or other physicochemical interactions. Once binding sites in the filter media are fully occupied, fine particles flow through in the filtrate, resulting in turbidity breakthrough. On the other hand, with high solids containing feed, pore, or flow channels within the filter media were progressively clogged with captured solids and the differential pressure across the filter gradually increases in response. In this case, mechanical sieving is the main capture mechanism since the characteristics (solids content, particle size distribution) of feedstock need to be considered while developing this application.

Table 2: Results on all three different approaches on mammalian cell culture clarification.

\begin{tabular}{|c|c|c|c|c|}
\hline & $\begin{array}{c}\text { Feed } \\
\text { Characteristics }\end{array}$ & $\begin{array}{c}\text { After centrifugation } \\
\text { followed by depth } \\
\text { filtration } \\
\text { [Option A] }\end{array}$ & $\begin{array}{c}\text { After primary } \\
\text { \& secondary } \\
\text { depth filtration } \\
\text { [Option B] }\end{array}$ & $\begin{array}{c}\text { After } \\
\text { microfiltration } \\
\text { by TFF } \\
\text { [Option C] }\end{array}$ \\
\hline Initial Volume (ml) & 2800 & 1000 & 800 & 1000 \\
\hline $\begin{array}{c}\text { Turbidity } \\
\text { Measurement } \\
\text { (NTU) }\end{array}$ & 96 & 3 & 1 & 4 \\
\hline $\begin{array}{c}\text { Mass of total } \\
\text { protein } \\
\text { (mg) }\end{array}$ & 5735.9 & 12.1 & 886.18 & 1776.5 \\
\hline $\begin{array}{c}\text { Protease } \\
\text { Concentration } \\
(\mu \mathrm{g} / \mathrm{ml})\end{array}$ & 0.31 & 4.104 & 5.955 & 5.730 \\
\hline $\begin{array}{c}\text { Product } \\
\text { Concentration } \\
(\mu \mathrm{g} / \mathrm{ml})\end{array}$ & 5.79 & & 2.8 & \\
\hline
\end{tabular}

\subsection{Microfiltration by Tangential Flow Filtration (TFF)}

In this application oriented study, the microfiltration technology is used to harvest the mammalian cells and cell debris from the fermentation broth. Here, the broth was concentrated slightly to the permeate sieving the cells and debris on membrane and two diafiltration volumes (DV) of buffer were performed. Target protein was washed into permeate tank and the cells were retained in the retentate tank. For the cross-flow MF, the membrane permeability is high since it has pore size of $0.45 \mu \mathrm{m}$ that nearly all the crossflow is converted to filtrate with very little TMP is applied. In this process, the $1.5 \mathrm{psi}$ 
of transmembrane pressure (TMP) was applied during the operation. Mostly process starts with very high initial flux and followed by dramatic flux decay due to high wall concentrations and high membrane fouling.

Generally in MF, the membrane resistance is negligible and the main resistance is from the cell cake \& membrane fouling. It has been believed by researchers that MF of high cell density fermentation needs to be operated at conditions of high shear rate and low TMP. The high shear rate reduces the cell cake thickness and low TMP prevents over compressing of the cell cake. However, due to shear sensitive mammalian cells, lower recirculation rate was used during the study. The samples were taken before and after the operation for turbidity measurement, total protein determination, quantification of protease released and recovery of target protein after the operation (Table 5 shows the result on option $\mathrm{C}$ ). The volume recovered in permeate was about $85 \%$ with the protease release as $4.1 \mu \mathrm{g} / \mathrm{ml}$ and little amount of target protein was lost in the retentate.

In this paper, the case study on comparison performance of clarification and recovery of Chimeric Anti-CEA mAbs from NSO cells is presented using three different harvest approaches consisting of centrifugation, depth filtration and microfiltration. Table 3 summarizes these results in terms of volume and final mass of target protein - Chimeric Anti-CEA mAbs recovery from NSO cell culture. It is evident that all three approaches offer feasible methods for harvest and offer comparable product clarification \& processing times except the vital product recovery.

Table: 3 Summary of clarification performance by different unit operations.

\begin{tabular}{|l|c|c|c|}
\hline & $\begin{array}{c}\text { Centrifugation \& } \\
\text { depth filtration } \\
\text { [Option A] }\end{array}$ & $\begin{array}{c}\text { Primary \& } \\
\text { Secondary depth } \\
\text { filtration } \\
\text { [Option B] }\end{array}$ & $\begin{array}{c}\text { Microfiltration } \\
\text { by TFF } \\
\text { [Option C] }\end{array}$ \\
\hline Protease release $(\mu \mathrm{g} / \mathrm{ml})$ & 12.1 & 2.8 & 4.1 \\
\hline Product Recovery $(\%)$ & 70.20 & 96.50 & 84.20 \\
\hline Volume Recovery $(\%)$ & 97 & 93.75 & 85 \\
\hline
\end{tabular}

Due to high shear occurred on mammalian cells during centrifugation, the option A has released $12.1 \mu \mathrm{g} / \mathrm{ml}$ of protease in comparison to the initial concentration of protease present in the sample $-0.31 \mu \mathrm{g} / \mathrm{ml}$. On the option $\mathrm{C}$, the microfiltration gave lower stress to cells and it has released about $4.1 \mu \mathrm{g} / \mathrm{ml}$. The primary and secondary depth filtration of option B had been a smooth operation with lowest release of protease as $2.8 \mu \mathrm{g} / \mathrm{ml}$ which leads to maximum recovery of target protein.

\section{CONCLUSION}

This study clearly concludes that NSO cell culture clarification using primary \& secondary depth filtration provides filtrate clarity of 1NTU on turbidity measurement, smooth and low stress on cells with the protease release of as $2.8 \mu \mathrm{g} / \mathrm{ml}$ in filtrate compare to other unit operation and lastly, this combination of depth filters with different retention ranges helps, to recover maximum of 96.5 percentage of Chimeric mAbs from NSO cell 
culture. However, the options of different clarification discussed in this paper differ significantly in the time required for development and optimization studies, scalability, cost of consumables, capital and other attributes of targeted product. Thus, it is recommended that these considerations be taken into account while choosing the optimal harvest approach for an application.

\section{ACKNOWLEDGMENTS}

The authors would like to acknowledge staffs of Innobiologics Sdn Bhd in the department of process science and quality control operations for contributing their help and guidance. Special thanks to our technicians Mr.Zulhusni Abd Ghani and Mr.Muhammad Ehsan for their help during experiments.

\section{REFERENCES}

[1] Reichert JM, Rosensweig CJ, Faden LB, Dewitz MC: Monoclonal antibody successes in the clinic. Nature Biotechnology 2005, 23:1073-1078.

[2] Gottschalk U: Process scale purification of antibodies, pp. 426. New Jersey: John Wiley \& Sons, Inc; 2009.

[3] An Z: Therapeutic monoclonal antibodies from bench to clinic. John Wiley \& Sons, Inc; New Jersey 2009.

[4] Van Dijk MA, Van De Winkel JGJ: Human antibodies as next generation therapeutics. Current Opinion in Chemical Biology 2001. 5:368-374 (2001).

[5] Morrison SL, Johnson MJ, Herzenberg LA, Oi VT: Chimeric human antibody molecules: Mouse antigen-binding domains with human constant region domains. In Proceedings of the National Academy of Sciences of the United States of America 81, 1984: 6851-6855.

[6] Gold P, Freedman SO: Specific carcinoembryonic antigens of the human digestive system. Journal of Experimental Medicine 1965, 122:467-481.

[7] Thomson DM, Krupey J, Freedman SO, Gold P: The radioimmunoassay of circulating carcinoembryonic antigen of the human digestive system. In Proceedings of the National Academy of Sciences of the United States of America 64. 1969:161-167.

[8] Hammarstrom S: The carcinoembryonic antigen (CEA) family: structures, suggested functions and expression in normal and malignant tissues. Seminars in Cancer Biology; 1999:67-81.

[9] Jefferis R: Glycosylation of recombinant antibody therapeutics. Biotechnology Progress 2005, 21:11-16.

[10] Chadd HE, Chamow SM: Therapeutic antibody expression technology. Current Opinion in Biotechnology 2001, 12:188-194.

[11] Chu L, Robinson DK: Industrial choices for protein production by large-scale cell culture. Current Opinion in Biotechnology 2001, 12:180-187.

[12] Hu WS, Piret JM: Mammalian cell culture processes. Current Opinion in Biotechnology 1992, 3:110-114.

[13] Russell E, Wang A, Rathore AS: Harvest of a therapeutic protein product from high cell density fermentation broths: Principles and Case study. In Process scale bioseparations for the biopharmaceutical industry. Edited by Shukla AA, Etzel MR, Gadam S. pp. 575. Boca Raton: CRC press, Taylor \& Francis Group; 2007. 